\title{
The Inefficacy of Naming Genocide in Contemporary Southeast Asia
}

\author{
Annie Pohlman \\ The University of Queensland, Australia \\ Email: a.pohlman@uq.edu.au
}

\begin{abstract}
This article examines two cases of ongoing persecution in Southeast Asia and the problems of naming either genocide. Specifically, I discuss the politics of naming the decades' long persecution of the Rohingya in Burma and West Papuans genocide. Both cases highlight some critical points of contention within the field of genocide studies which revolve around competing conceptions of how and what genocides destroy. Often separated into liberal and post-liberal camps, or those which conceive of genocide as a crime or as a process, these competing views create deep divisions over what cases of mass violence can be named genocide, or not. I take up some of these highly politicized and moralistic debates around the naming of genocide in light of these two contemporary Southeast Asian cases; that of the Rohingya which arguably has been recognised as a case of genocide since the latest wave of violence in 2017; and the case of West Papua, which remains very much at the fringes of genocide studies. I also draw on the work of a range of scholars who question the "effectivity" of naming genocide. I argue that, in these two contemporary Southeast Asian cases, naming (Rohingya) and not-naming (West Papua) cases of ongoing persecution genocide has had little effect whatsoever.
\end{abstract}

Keywords: Southeast Asia; Rohingya; West Papua; genocide

\section{A NAME AND ITS UNFULFILLED PROMISE}

When we consider cases of murderous destruction of human groups in the contemporary world, there are undeniably fraught and highly politicized and moralistic debates over the naming of this destruction as genocide, or not. ${ }^{1}$ When Raphael Lemkin (1944) coined the term in the midst of the Second World War's atrocities, he rejected previous terms used to describe the extermination of the Hereros and Namas by German colonial authorities at the start of that century, or the Armenians and other minorities at the end of the Ottoman Empire, terms such as "mass murder" or "völkermord" (the murder of a nation/ people) (Becker, 2008; Schaller, 2011). Instead, Lemkin created a new name, genocide, the term which was then taken up and codified in one of the first conventions of the newly-formed United Nations and, indeed, which became "one of the most powerful in any language, and [...which] reshaped the moral landscape of the world" (Luban, 2006, p. 307).

More than seven decades after the establishment of the 1948 UN Convention on the Prevention and Punishment of the Crime of Genocide, the world has failed to prevent too many cases of genocide (see Mayersen, 2013). On every inhabited continent, genocides have continued to ravage populations in this supposedly modern era of the international community's promise of never again (see Grünfeld \& Vermeulen, 2009). In the post-Second World War period, there have been-and are- too many cases of genocide, claiming irrevocably the lives and futures of so many. While Lemkin's term may have reshaped the moral landscape and given a name to those atrocities which the world found almost impossible to describe during WWII, the promise that the 
international community made to prevent these atrocities being inflicted on any others has not been fulfilled. With so many dead and injured, dispossessed and destroyed through genocide in the last seven decades alone, that promise of "never again" has rung hollow, leaving only irreparable harm in the wake of our collective inaction.

In this article, I take up some of the highly politicized and moralistic debates around the naming of genocide, and the effects of that naming. By engaging the work of a range of scholars who have pushed our field of comparative genocide to question how and what genocides destroy, I echo Christopher Powell's question (2007), what do genocides kill? ${ }^{2}$ To answer this question, I take a broad and inclusive understanding of what genocide is, beyond that of how the crime is defined in legal codifications.

Specifically, I discuss two contemporary cases which began-and which continue-in the postGenocide Convention era in Southeast Asia, and the naming of them as genocide: that of the Rohingya in Rakhine state in Burma, and the indigenous peoples of West Papua. Neither case is new, in the sense that both have arguably been in train for decades, though the latest wave of violence in Rakhine state since 2017 has garnered some international political and media attention. Rather, both cases, for the majority of their histories, have remained on the fringes of comparative genocide studies, just two of the many post-WWII cases rarely considered. Neither case, despite its longevity, belongs to the "canon" of genocide studies which include contemporaneous cases, such as the Democratic Kampuchea regime in Cambodia (1975-1979), Rwanda in 1994, and the former Yugoslavia during the 1990s (Bloxham \& Moses, 2010; Irvin-Erickson, La Pointe \& Hinton, 2013).

Stepping beyond the canon to those cases which remain on the fringe of genocide studies, I take these two Southeast Asian examples and consider the "effectivity" of naming them genocide (see Powell, 2007 pp. 529-530). On the face of it, naming the ongoing targeted persecution of Rohingas and West Papuans genocide seems a straightforward matter, at least in terms of that persecution being carried out against one of the protected types of groups, the "national, ethnical [sic], racial or religious" groups currently listed in the Genocide Convention; in these two cases, ethnic groups (Convention on the Prevention and Punishment of the Crime of Genocide, 1948, art. 2). Yet neither case is straight-forward and both have evoked criticism when framed as genocide. Naming the destruction of West Papua's indigenous peoples genocide continues to be viewed as the fevered hyperbole of foreign human rights activists. ${ }^{3}$ Prior to 2017 , there was rarely any discussion of the persecution of Rohingyas outside activist circles within Southeast Asia (see Southwick, 2015).

I argue that these two cases highlight some of the most acrimonious debates within genocide studies, on two inter-connected issues: what is genocide, and what cases can be named genocide. Within the field of comparative genocide studies, it is on these points that some of the bitterest contentions lie. Fundamentally, these contentions are between two camps, summarized by Dirk Moses (2002) as "liberal" and "post-liberal" concepts of genocide. The first are those who hold to a "narrow", legal (liberal) paradigm which emphasizes the physical extermination through mass killings of the victim group, committed with intent by (mainly) a state. The second are those in the broader "post-liberal" camp, one which is strongly associated with proponents of cultural genocide, and which emphasizes the processional nature of genocidal violence; violence which encompasses more than extermination through killing and by a wider range of actors. ${ }^{4}$ In some ways, the latter focuses on what Tony Barta (1987) calls "genocidal outcomes" while the former stresses genocidal intent and evidence of direct acts, as listed in the UN Genocide Convention. The former has a narrow, legalistically-determined answer to Powell's question-what do genocides kill?_-offering a narrow scope for who the victims of genocide are/can be. The latter encompasses victims from a much wider range of human-made catastrophes which have seen human collectivities destroyed and eroded. Within the field, some authors see the latter as a "Lemkinian Turn" or a redress of the narrower, legalistic interpretations which dominated genocide studies during its first stage of development (see Muller, 2017, p. 101).

To examine how the Rohingya and West Papuan cases highlight what is at stake in these debates, I outline each case in the following sections. In each case, I address these debates over what is destroyed in genocide and how, and the contentions over naming them genocide. However sharp the field's debates over naming genocide may be, and however much the persecution against these two groups may match even more liberal concepts of the crime, the term has been essentially meaningless in its effect for either the Rohingya or the West Papuans. The Rohingya case is, arguably, now seen as a case of genocide, but this has meant very little for the victims. In West Papua, not-naming this ongoing persecution genocide has also meant very little for the victims. While I agree with Powell when he argues that "a genealogical emphasis on the effectivity of classifying practices [... brings] out the practical political stakes that have fuelled dissention over 
the meaning of 'genocide'," these two cases highlight just how hollow the term is (Powell, 2007, p. 530). Our liberal and post-liberal arguments, rather, reveal only the lack of "effectivity" when classifying some human tragedies as genocide and others as somehow lesser tragedies.

\section{NAMING GENOCIDE: THE ROHINGYAS OF BURMA}

The UN special advisor on the prevention of genocide, Adama Dieng, made a trip to Bangladesh in early March 2018 to assess the condition of nearly 700,000 refugee Rohingyas who had fled Burma (Myanmar) in the months prior. At the conclusion of this trip, he stated, "Rohingya Muslims have been killed, tortured, raped, burnt alive and humiliated, solely because of who they are. All the information I have received indicates that the intent of the perpetrators was to cleanse northern Rakhine state of their existence, possibly even destroy the Rohingya as such, which, if proven, would constitute the crime of genocide" (quoted in 'Note to correspondents', March 12, 2018). To no-one's surprise, senior officials from Burma immediately rejected any findings of "genocide or ethnic cleansing"; U Myint Thu, the secretary for foreign affairs, added that those Rohingya who had fled the country "can come back anytime at their convenience" (cited in Beech \& Nang, 2018). At the time of writing (late 2019), the Burmese government had not allowed any independent investigations into the violence against Rohingyas within the Arakan region itself (Rakhine state), on the west coast of the country (see, for example, Murdoch, 2017). It was not until late 2018 that a UN independent fact-finding mission established by the Human Rights Council found that the Burmese security forces were carrying out the destruction of the Rohingya with "genocidal intent" ('Report of the Independent Fact-Finding Mission on Myanmar', 12 September 2018), and the International Criminal Court's prosecutor confirmed that they would investigate the deportation of the Rohingya (International Criminal Court, 2018).

This genocide against the Rohingya people is not new, nor are there any serious current efforts being made to prevent their persecution (Adams, 2019). Although the world's attention hovered briefly in 2017 and 2018 on their plight-and the world's press focuses less on the atrocities themselves and more on castigations of Burma's Daw Aung San Suu Kyi for failing to stop the military's ethnic cleansing campaign against the Rohingya (e.g. Caryl, 2017; Schwirtz, 2018) -efforts to cleanse the Rohingya from Burma are decades old.

The modern, post-colonial state of Burma was founded on ethno-nationalist grounds and has a long, fractious and frequently violent history of persecution of minority ethnic groups, particularly the majority-Bamar military (Tatmadaw) persecution and civil war against the Karen, Kachin, Shan, Chin and other minorities (see Callahan, 2013; Gravers, 2015). Ethnic difference, at best fluid in pre-colonial days, was solidified and politicized under the British to create the various "national races" (taingyintha) of Burma (Cheesman, 2015, pp. 101-107). Over time, to be one of the taingyintha meant inclusion within the modern nation (the civil war against particular national races notwithstanding), to be non-taingyintha meant to be foreign or outsiders in the military's conceptualization of the Myanmar unitary state. As Nick Cheesman explains, "national-race identity [functions] to represent the integrity of the nation and exclude interlopers claiming to be members of the political community 'Myanmar"' (2017, pp. 473-474).

Although the primacy of "national races" and the centrality of being taingyintha has long been part of post-colonial Burmese legal and other concepts of the Burmese polity, a citizenship law passed by the military regime in 1982 meant that being a member of one of the national races became "the primary basis for citizenship" (Cheesman, 2017, p. 471). Rohingya are not-and have never really ever been considered to be-part of the taingyintha. During the early democratic government under $\mathrm{U} \mathrm{Nu}$, they were recognized as a Burmese minority group and were given some provisional citizenship rights (national registration cards, voting rights, etc.); however, after Ne Win took power in a military coup in 1962 , these provisional rights were gradually stripped away (Arcaro \& Desaine, 2008, pp. 152-160). Under $\mathrm{Ne}$ Win's junta, citizenship underwent a process of "Burmanization" whereby the military administration went about determining who was counted within the taingyintha, and therefore Burmese, and who was not, solidifying the boundaries of the "national races" (Arcaro \& Desaine, 2008). Under Ne Win, and under the 1982 citizenship law, the Rohingya were demarcated as definitely not taingyintha; they were therefore more than simply not Burmese, they were foreign interlopers who did not belong in-and therefore must be expelled from-Burma (Zarni \& Cowley, 2014).

This more recent narrative justifying expulsion, framed in citizenship terms, only serves to reinforce existing negative and exclusionary discourses about Rohingya. For the majority of the population in Burma, the Rohingya have ever been perceived as foreigners (they are thought to be migrants from Bangladesh) and it is on this basis that discrimination and persecution 
against them are often justified. ${ }^{5}$ Direct violence against Rohingyas in Rakhine state is decades old and, since the late 1990s in particular, they have been reported to be the "most persecuted minority" in the world (Leider, 2016, p. 159).

Tensions between Buddhists and Muslims in the Arakan region, already marked by sporadic violence under the British, escalated during WWII: as the British retreated and the Japanese advanced, the British armed the Muslims while the Rakhine Buddhists mostly joined the Burmese independence movement (supported by the Japanese) under the nationalist leader, Aung San. After the war ended, the Rohingya were further accused of being disloyal to the new Burmese state as local mujahidin forces fought for independence against the government in the 1950s (Sardiña Galache, 2014). It was really during this period that the term "Rohingya"-although the word had existed since centuries earlier-came to mean a separate Muslim identity in Rahkine, as part of this independence movement by the Mujahid rebellion (see Leider, 2016). From then until the more recent crisis from 2012, there have been two major exoduses of Rohingya refugees from the Arakan region across to Bangladesh: the first in 1978 as a reaction to one military campaign, forcing over 200,000 to flee; the second in 1991-1992, when over 250,000 fled another military campaign of terror and expulsion (Grundy-Warr \& Wong, 1997; Human Rights Watch, 1996; Zarni \& Cowley, 2014).

For at least the last two decades-including since the slow democratization reforms began in late 2010-a range of UN bodies has been documenting systemic rights abuses against the Rohingya people (Human Rights Watch, 2013). The most recent crisis began in 2012 with anti-Muslim riots, sparked by the alleged rape of a Buddhist woman by Muslim men, leading to communal violence and the targeting of Rohingyas in Rakhine (Robinson \& Rahman, 2012). The depiction of this violence as "intercommunal" or "sectarian", however, belies the role of the Burmese state, and the military in particular, in this violence (Zarni \& Cowley, 2014, p. 718). While these initial attacks did involve civilian participation and incitement, they were supported by government forces. As Human Rights Watch (2013, p. 4) reported, these attacks were "organized, incited, and committed by local Arakanese political party operatives, the Buddhist monkhood, and ordinary Arakanese, at times directly supported by state security forces." As one commentator has put it, "the Rohingya's cultural, religious and linguistic differences [have] made them expedient scapegoats in the context of a failed process of nation-building. Nothing glues together a divided community more than a common threat, real or imagined, and nothing has united the Rakhine and the Bamar more than identifying the Rohingya as their common enemy" (Sardiña Galache, 2014, p. 15). Furthermore, by standing by and doing nothing to stop civilian attacks on Rohingya - and by participating in the attacks- the Burmese government allowed complete impunity for the initial wave of violence in 2012 (Zarni \& Cowley, 2014).

Since 2012, violence against Rohingya (and some other Muslim communities) has spread and involves acts of terror and violence committed by military and civilian actors to force them to flee. In addition, the Burmese government has continued to block independent investigations or international aid to Rakhine state. ${ }^{6} \mathrm{~A}$ range of major research reports since 2012, based mostly on refugee accounts, has concluded that the Rohingya people have been persecuted through ethnic cleansing, crimes against humanity and, in some findings, genocide: by Human Rights Watch (2013) in 2013, by the Yale Law School in 2015 (Lindblom et al., 2015), and by the International State Crime Initiative at Queen Mary University also in 2015 (Green, MacManus \& de la Cour Venning, 2015). All have found evidence of systematic violence being used by state and civilian forces against the Rohingya people including massacres, torture, rape and other forms of sexual and gender-based violence, destruction of their homes, land seizures, forced labour and numerous restrictions on the rights of Rohingyas as stateless peoples within Burma. As Rohingya have fled the country-many making dangerous journeys overland or by sea-they have found some refuge in neighbouring countries: the greatest number are in Bangladesh, but others have escaped to Malaysia and Indonesia, and a smaller number to Saudi Arabia, where they have found work as migrant labourers in construction (Hoffstaedter, 2017).

More recently, after an investigation amongst Rohingya refugees in Bangladesh in September 2017, the Office of the High Commissioner on Human Rights released a report saying that the Burmese military had recommenced its "clearance operations" in northern Rakhine State in August 2017 (OHCHR, 2017). Another major report released in March 2018 by Amnesty International used satellite imagery, photographs and videos to show that state authorities have "embarked on a major operation to clear burned [Rohingya] villages and to build new homes, security force bases and infrastructure in the region", making the likelihood of a future, peaceful repatriation of displaced Rohingya unlikely (Amnesty International, 2018, p. 3). A large percentage of the approximately one million Arakan Rohingya has been 
expelled from Burma and the possibility of their safe return is remote.

Report after report by various UN bodies, by international NGOs and researchers has been released, documenting the atrocities and condemning the Burmese government for their treatment of Rohingya. At the time of writing in late 2019, Amnesty International continues to report on violence against ethnic minorities by the Burmese military in Rakhine state (Shelton, 2019). The widespread and systematic nature of the persecution against them is well-documented and well-known; there can no longer be any question that these crimes are in progress. Regardless of the overwhelming evidence, the Rohingya people continue to be persecuted and continue to flee the violence in Rakhine state. Aside from some condemnation, the international community has made no move to halt the violence.

The genocide against Rohingya people continues today, unabated, as it has, arguably, for more than thirty years. In the post-1945, post-Holocaust, post-"never again" era, genocides continue, unabated and unstopped, just as they ever have. The visibility of this genocide after 2017, a result of the international coverage that the latest wave of attacks against Rohingya in Burma has garnered, albeit briefly, has had no effect. Even as UN investigatory bodies cite evidence of genocidal intent behind the many atrocities used by the Burmese military against Rohingyas, and the International Criminal Court undertakes its preliminary investigations into the forced deportation of Rohingyas into Bangladesh, calling these atrocities genocide has had little actual effect (ICC, 2019). Naming genocide in this case has meant almost nothing for the victims.

\section{NOT-NAMING GENOCIDE: WEST PAPUA}

How do we understand genocide in the modern, post1945 period? As both an idea and as a law, as a concept of violence which destroys whole peoples and as a crime to be prosecuted, genocide has emerged as one of the most contested, and morally imperative, concepts of the modern era (see Powell, 2004; Shaw, 2015). For this article, the tensions between the liberal and postliberal understandings of genocide play out repeatedly in arguments over understanding genocide as a process of destruction on the one hand, and as an offence under international law on the other. These tensions become critical when we ask, who have been (and currently are) the victims of genocide? These tensions are critical because they police the boundaries of who the victims of genocide are/can be. As Christopher Powell (2007) has asked, it comes down to "what do genocides kill?"

It is only after Lemkin that the idea of genocide has existed as either a concept of group destruction and as a crime, and yet the post-1945 period has seen such a wide-and deeply contentious - range of attempts to annihilate groups of unwanted people. It has been during this period that the world has witnessed human catastrophes whereby millions have been wiped out because they were unwanted or they were the wrong type of people. Cases such as in Cambodia in 1975-1979, in Bosnia-Herzegovina in 1992-1995, in Rwanda in 1994, and in Darfur (since 2003), are seen as genocides of this modern era, within common understandings of the phenomenon, if not always in a legal sense. ${ }^{7}$ Yet there are many comparable cases from the same era. Rarely are these cases called genocide, and yet these human-made disasters claimed the lives of millions. When looking at Asian cases alone, these include: the Partition of India in 1946-1947 (Brass, 2003); the occupation of East Timor by Indonesia between 1975 and 1999 (Saul, 2001); the massacres of Communists in Indonesia in 1965-1966 (Melvin \& Pohlman, 2018); East Pakistan (Bangladesh) in 1971 (Jahan, 2009); Mao's Great Leap Forward of 1959-1961 (Dikötter, 2010) or the Cultural Revolution of 1966-1976 (Yang Su, 2011); and during so many other cases of mass death and destruction. As Christopher Powell (2004, p. 80) explains, 'How 'genocide' is defined affects not only which events are labelled genocides and which are not, but by implication how the moral, political, and legal energies mobilized by 'genocide' will be applied." In this second section, I look to one of the many cases on the fringe of the field of genocide studies, that of West Papua, to examine victimization and genocidal violence. Specifically, I delve into these tensions between understanding genocide as a process and as a crime, to hopefully move beyond the typologization and competing paradigms of what genocide is, to focus on victims and victimization during periods of mass human violence (see Stone, 2008).

There are too many cases of genocide happening today, whether they are named genocide or not. Many are the eroding, corrosive and devastating "slow-motion" genocides of the modern era. These genocides inexorably destroy peoples who are not welcome in the modernnation states' borders drawn over their ancestral lands, or who are not the right kind of people to live and prosper in those states (Moses, 2002; Rosenberg, 2012). Such cases range from those described as the "benign" and "unintended" (to imagine such terms in relation to genocide) to active policies of elimination. ${ }^{8}$

In many of these contexts, this slow erosion of 
people, culture, heritage and language is the direct result of both colonial expansionism across the continents of the world and the policies of the post-colonial states established in the last century. Many of these states, based on particular ethno-nationalist polities, such as that of Burma, are more than just exclusionary to those groups of people left stateless, if not homeless, within their borders. For minorities whose ancestral homes sit within and across the borders of these nation-states, belonging to, if not having the protection of, these states remains tenuous. The traditional lands of the numerous ethnic minorities of the highland regions of mainland Southeast Asia stretching down from the Tibetan Plateau, for example, now sit across modern-day Viet Nam, Laos, Burma, Thailand and Cambodia. Many of these minorities, such as the Degar Montagnards from the highlands and the Khmer Kampuchea Krom peoples from the Mekong Delta, are seen as fundamentally different from the majority ethnic groups of these states. Their traditional swidden lifestyles and alleged separatist inclinations have been used to justify violence against these groups by these states for decades, including with systematic religious persecution, arbitrary arrest, and numerous other forms of repression, all of which erodes and destroys these groups over time (Cotton \& Pohlman, 2011).

Not all states where ongoing genocides are unfolding are post-colonial, of course, many remain settler colonies. To speak of the post-colonial in many states around the world denies the sovereignty of the first nations peoples whose lands were colonized, and which remain colonized (Moreton-Robinson, 2003). Australia, Canada and the United States of America are all examples of settler-colonial nations where the indigenous inhabitants-decimated during the early periods of first contact and colonial expansion-continue to experience the erosion of their peoples, languages and cultures (Wolfe, 2006; Short, 2016). Thus, when we speak of genocides of the modern, post-1945 era, the ongoing genocides which began hundreds of years ago must be included. They have not ended, nor do they constitute crimes under international law as it exists today (Moses, 2018). And yet, through their physical, biological, social, cultural, economic and political destruction over time, it is an injustice to not understand the erasure of indigenous peoples as genocide.

To examine who are the victims of genocide, and how they experience genocide, I turn here to the highly contentious case of West Papua to probe some of the tensions between genocide-as-process and as a crime under international law. West Papua encompasses the western half of the island of New Guinea; located to the north of Australia, sharing a border with the eastern half of the island, Papua New Guinea. The territorywhich is blessed/cursed with tremendous mineral and other natural resource wealth (ICG, 2002)-currently covers two provinces of Indonesia: Papua and West Papua (here, both are referred to as West Papua). The case of West Papua vexes a number of definitional and conceptual debates within genocide studies: it is a case of colonization, by both older European colonizers and then again by a post-colonial state, Indonesia; it includes a range of acts of annihilation, from mass killing through to corrosive social and cultural destruction; and it shows how intent might be uncovered or inferred on the part of the Indonesian state (see Short, 2016).

There are a number of well-established central points to be considered in this discussion of West Papua as a case of genocide. First, the region was forcibly annexed and occupied by Indonesia. The former Dutch colony, West Irian/New Guinea, was a point of contention after the Dutch finally recognized Indonesia's independence in 1949 , many in Jakarta seeing the colony as a natural part of the new nation (Penders, 2002). Sukarno, Indonesia's first president, launched his infamous "Trikora" ("Peoples' Triple Command") campaign to "liberate" West Irian from the Dutch in 1961, mobilizing military and civilian forces. By early 1962, the Dutch were in US and Australiansponsored talks with the Indonesians, eventually leading to the signing of the New York Agreement in August that year. The US supported Jakarta's bid for the territory, worried that the mass-supported Indonesian Communist Party would exploit the issue to gain more power, and so "completely ignored the right of self-determination for the Papuans" (Penders, 2002, p. 441). By the end of 1962, the Dutch had withdrawn from the territory and Indonesian troops had arrived, despite the Agreement mandating a UN transitional authority (UNTEA, the United Nations Temporary Executive Authority) for at least another year (Saltford, 2002). As Brad Simpson explains, once the Indonesians arrived, they "sought to both undermine UNTEA's authority and violently suppress Papuan resistance to the pending takeover. The United Nations and the international community responded with utter silence, so eager were they to declare success and so unwilling to challenge Jakarta to effectively protect the political rights of the Papuan people" (Simpson, 2003, p. 472).

Under the New York Agreement, the UN was required to oversee a process to ascertain the will of the people in Papua; the process held was the infamous "Act of Free Choice" in 1969, more commonly known as the "Act of No Choice" (Macloed, 2015, p. 53). Instead of a 
plebiscite, approximately 1000 carefully-selected leaders from various Papuan tribes, over a period of about two weeks from mid-July until early August 1969, were asked to declare either for independence or to become part of Indonesia. According to the Indonesian accounts of this process, they were met with enthusiastic acclamations to join Indonesia. According to Papuan accounts, the tribal leaders were threatened and coerced by the Indonesian military to accede (Saltford, 2002, pp. 158-165). Leading up to the Act of Free Choice, the Indonesian military had carried out aerial bombings of villages, shot and killed Papuan civilians in massacres with machine guns, as well as tortured and disappeared those who protested Indonesian control (Macloed, 2015, pp. 53-56).

Second, many West Papuan people have resisted the occupation since before it began. There are reports of clashes between West Papuans and Indonesian forces beginning in 1962 (Budiardjo \& Liong, 1988, p. 13). The desire on the part of West Papuans to be an independent, sovereign nation has remained strong since before the Indonesians arrived; according to Richard Chauvel, "Papuan nationalism is stronger today than it was in 1961, when the Morning Star flag [the West Papuan independence flag] was first raised" (2005, p. x). During the seven years between the Indonesian troop arrivals and the Act of Free Choice, there were numerous largescale resistance attempts from local Papuans against the Indonesian military, such as in Muanemani and Enarotoli in the Piniai region (Budiardjo \& Liong, 1988, pp. 20-22). By 1964, parts of the rebellion had coalesced to form the Free Papua Movement (Organisasi Papua Merdeka, the OPM), made up of a broad spectrum of the West Papuan population, tribal and urban (Aspinall \& Berger, 2001). The OPM, however, has never been the kind of large and well-organized military resistance that was seen in other parts of the archipelago, such as in East Timor and Aceh. Rather, as Jason Macleod explains, from “1965 to 1998 the core of resistance to Indonesian rule was waged by poorly armed and numerically small numbers of Papuans operating in a network of decentralized guerrilla groups based in the rugged mountains and dense jungles of the interior" (Macloed, 2015, p. 167). Moreover, in his study of Papuan resistance to Indonesian rule over time, Macleod found that although armed struggle has continued to this day, the younger generation in particular "are much more actively engaged in nonviolent rather than violent resistance to Indonesia rule and that this tendency is increasing over time" (2015, p. 168). In recent years, this resistance has reached out to other countries in Melanesia to support their claims for independence: in 2014, Papuan leaders established the United Liberation
Movement for West Papua (ULMWP), supported by Vanuatu (Hernawan, 2017).

Third, a large number of West Papuans have died since Indonesia took over in 1962. The number killed is unknown, as is the number who have perished from privations: estimates range from a minimum of 150,000 to more than 500,000 (Philpott, 2018, p. 260; Macloed, 2015 , p. 58). West Papuans have been murdered in mass killings of varying sizes and durations: during regional-based massacres over a period of months, such as in the Manokwari region throughout 1967, in the highland regions in 1977 (Budiardjo \& Liong, 1988, pp. 41-65), as well as in more localized massacre events, such as in Biak on 6 July 1998 (Rutherford, 1999). The Indonesian military uses terror and violence to subdue West Papua, and routinely carries out brutal crackdowns on suspected OPM and others who resist Indonesian rule (Hernawan, 2018). Some of these crackdowns have led to West Papuans becoming refugees, most fleeing across the border to Papua New Guinea, such as in 1984, when thousands fled one such military action (see Macloed, 2015). Human rights abuses are routinely and systematically inflicted against the West Papuan population, particularly against those attempting to advocate for independence or political change (see Hernawan, 2018). Verifiable information on these abuses is difficult to obtain: the Indonesian government maintains a decades' long restriction on foreign reporters, UN officials, representatives of international aid groups and numerous others from entering West Papua, and Indonesian journalists face similar obstacles in reporting on the area (Human Rights Watch, 2015).

Another factor which cannot be discounted is the very clear demographic change in the population in West Papua. As part of Indonesia's colonization project, large numbers of migrants from other parts of the country (notably Java) have settled in West Papua over the last five decades. In one study published in 2010, it was estimated that migrants now outnumber Papuans, 52 to 48 percent (see Elmslie, 2010). These internal migrants have been drawn by West Papua's vast resource-extractive sectors and incentivized through the "transmigration" program (which moved poor internal migrants from the overcrowded islands, such as Java, to the lesser-populated islands) (see Hoey, 2003). Javanese, Buginese, Butonese and other non-Papuan ethic groups have also been drawn by labour opportunities, trade, and fishing (see Budiardjo \& Liong, 1988, pp. 46-53).

Over the five decades of this demographic shift, however, an abysmal economic disparity has emerged between the migrants (enriched through their participation 
in the resource extraction industries) and the severe impoverishment of the majority of Papuans (Macleod, 2015, pp. 49-80). These clear economic divisions, growing demographic change, and marginalization of the Papuan population feeds local notions that the Papuan people are being slowly wiped out. As Jason Macleod (2015, pp. 6667) explains, the "experience of demographic change and the fear that Papuans will disappear as a people resonates broadly and deeply. This structural violence is reinforced by the cultural violence of racism and a dehumanized view of Papuans [within Indonesia] as enemies of the state."

To return to the main question, is this a case of genocide? If taking a legal measure, could the occupation of West Papua by Indonesia be prosecuted as a crime (or, more precisely, could individuals within Indonesia's government or security apparatus be indicted)? Specifically, have these individuals committed acts done with intent to destroy, in whole or in part, the West Papuan people? The short answer, if asking the legal question, is no. But it is a qualified no, because it is less about the egregious nature of the allegations and more a matter of what evidence can be found and supported.

While some scholars and advocate groups have attempted to argue the case, it is difficult to prove that the crimes committed by state forces in West Papua were/are genocide. These reports and investigations have examined, amongst other topics: the racial/ethnic group targeted for violence; the elements of crime in relation to specific acts of genocide, such as cases of massacres, torture, sexual violence, and other egregious abuses; who had command responsibility for, and who are suspected of carrying out those acts; as well as how intent on the part of perpetrators might be inferred. ${ }^{9}$ The findings in these studies and reports show that there is evidence of acts of genocide, specifically against West Papuans, though showing intent that these acts were done to wipe out the West Papuan people as such is a much murkier prospect. With West Papua closed to outside scrutiny and reports of abuses difficult to verify, there is little chance that the details necessary to build a case against any perpetrator is or would be possible, even if there were the political will to prosecute, either domestically or internationally. ${ }^{10}$ Furthermore, those who object strenuously to the claims that abuses are widespread and systematic employ a range of arguments to discredit and undermine such claims, all derived from lack of access: the numbers are inflated and cannot be verified; the methods used to find out the information are flawed; the paranoia of West Papuans that they are being wiped out feeds the propaganda created by foreigners who wish to interfere in internal Indonesian affairs; outsiders create stories about West Papua (to discredit Indonesia) and have no understanding of matters "on the ground". ${ }^{11}$

And yet, there is no argument-by either supporters or detractors - that West Papuans have been killed, at least in their tens of thousands, if not in their hundreds of thousands. There is no argument that West Papuans are now a minority within their traditional lands, and that they are, by far, one of the most impoverished peoples in the Indonesian nation. While the level and rate of violence against West Papuans by the Indonesian state's security services are hotly contested, the fact that this violence has happened and continues is not. The explanations for the use of this violence are also highly divergent: on the one hand, these are acts of terror and suppression done to destroy a group; on the other, they are legitimate measures taken by the Indonesian state to ensure their territorial integrity (see Philpott, 2018; Hernawan, 2018).

The legal measure of what constitutes genocide, by itself, falls a long way short of adequately describing the ongoing persecution against, and destruction of, the indigenous peoples of West Papua, as is also the case for so many other genocides in the modern era. As a crime, the word means little in this case, and there is no justice in a hollow not-naming. So, if we turn away from conceptualizing genocide purely as an offence under law, the question then becomes, is there a genocidal process underway in West Papua? The short answer is yes. Over the last five decades, West Papuans have experienced systemic violence and seen their people, land and culture slowly destroyed and the Indonesian state is responsible for this violence. If genocide is essentially a process by which a people are eliminated, then the answer is yes. In the end, however, it is neither the question nor the answer that actually means anything, it is the fact that we do nothing to stop the violence in West Papua.

\section{THE INEFFICACY OF NAMING GENOCIDE}

The case of West Papua brings us back to Christopher Powell's fundamental question, "what do genocides kill?" This question is about more than legal certainty or semantics, it demands that we assess who is lost, and how, through genocide, essentially grounding our understanding of what the word means. As Dan Stone (2008, p. 4) so flippantly_and so insightfully-put it, “One man's genocide is another man's unfortunate bout of disease-driven 'population readjustment'."

The two cases of long-term eradication against groups that I have discussed here-one on mainland Southeast Asia, the other on the western side of Papua, 
in the disputed territory annexed by Indonesia—-highlight a number of issues. First, for most of their histories, both cases were very much on the fringe of genocide studies, and on the fringes of international interest. The latest waves of violence against the Rohingya in Burma's Rakhine state since 2017 have seen this case (finally) understood as a case of genocide, with some of the atrocities perpetrated against this group by the Burmese military in their forced expulsion to Bangladesh currently under investigation by the ICC. The West Papuan case, however, remains very much on the fringe of the field of comparative genocide studies.

The second issue that these two Southeast Asian cases highlight relates to the fundamental tensions between these two camps within genocide studies, between conceptions of genocide as a crime under international law and as a process; or, to use Dirk Moses' descriptions, between liberal and post-liberal views (2002). The persecution of the Rohingya and West Papuans can, I would argue, match both conceptions. Taking the liberal view, both groups have had elements of the crime of genocide perpetrated against them by state forces, including mass killings and other acts of crime, as they are listed in Article II of the Convention. ${ }^{12}$ The drawn-out nature of the destruction of the Rohingyas and West Papuans, however, also matches the post-liberal understanding of genocide, the processional nature of the violence over decades very much highlighting the importance of looking at Barta's (1987) "genocidal outcomes" in the slow erasure of a people.

When we consider who have been the victims of genocide in the modern, post-Genocide Convention era, then I echo those who focus on the outcomes of the (too) many cases, past and ongoing, from the last seven decades. I agree with those such as Powell that the "effectivity" of classifying some cases as genocide and others as somehow lesser because they do not meet the elements of the crime is not just logically flawed, it is an essential wrong.

The greater wrong, however, is that these debates over what genocide is, and who is killed through genocide, and therefore which cases can be named genocide are essentially meaningless. They are meaningless, or without effect, in the sense that the naming of genocide has no impact on our relentless, knowing, collective inaction. As the Rohingya and West Papuan cases highlight, whether the persecution of a people is named genocide or not, there is no effect from the naming.

After the world paused, albeit briefly, at the end of the Second World War and promised never again, never again will we allow this destruction to be carried out again, the greater wrong is that we have willingly, knowingly taken part in or permitted these atrocities against so many. If we ask ourselves, who are the victims of genocide right now, today, will it ever make a difference? If naming Burma, or West Papua genocide, will that mean that people in Burma or in West Papua will stop dying? The answer is no. They are the human residue of so many genocides left unnoticed and unmourned, just as so many others have been left unnoticed and unmourned before them.

\section{ENDNOTES}

1) Thank you to the anonymous reviewers for their feedback on this article; their input has strengthened the arguments and examples used herein.

2) For one recent volume in which a number of the contributors engaged in these debates, see Murray (2017).

3) See, for example, Darroch (2009) and Anderson (2015). Darroch, Anderson and others do draw attention to some of the more problematic elements within those activist campaigns; for a more nuanced discussion, see Philpott (2018).

4) For a critique of these debates, see, for example, Powell (2007) and Short (2016) and, for more on genocide as a process, rather than as a (somewhat) discrete physical event, see Rosenberg (2012).

5) See Leider (2016) and Gravers (2014). Nearly 90\% of the population are Buddhists, but some ethnic minorities (such as the Chin, Kachin and Karen) practise Christianity, with some indigenous faiths still observed. Although Muslims make up nearly 4\% if the population, and Islam has a long history in Burma, its followers are often associated with "foreigners": the Rohingya are the case in point, but other Muslim groups are also seen as foreign traders, such as the Pathi, from Persian/ Indian origin, or the Panthay, originally from Yunnan. See Moshe Yegar (1982) and Gravers and Ditlevsen (2014).

6) See Zarni and Cowley (2014), pp. 716-720. Some examples of the Burmese government blocking aid include their bans on allowing access for medical aid from MSF (Doctors Without Borders). In February 2014 and August 2017, the government has forced MSF to cease all operations in the country: they had primarily been treating thousands in Rakhine state, most of them Rohingya. See Zavis (2014) and Doctors Without Borders (2017).

7) All sit within the "canon" of genocides (see Bloxham $\&$ Moses, 2010). The case of Rwanda, however, is 
the only one which is accepted as genocide within international law: in the first Judgment handed down by the International Criminal Tribunal for Rwanda (ICTR) in 1998, the court issued the world's first conviction for genocide in an international tribunal against the mayor of the town of Taba, Jean-Paul Akaeysu. See Prosecutor $v$ Akayesu (Case No ICTR-96-4-T), Judgment, 2 September 1998. The specific case of the massacre at Srebrenica has also been ruled genocide. In relation to the atrocities committed and tried before the International Criminal Tribunal for the former Yugoslavia (ICTY), most charges have related to crimes against humanity and war crimes; there were only two successful prosecutions for charges relating to genocide, both regarding the massacre at Srebrenica, see Prosecutor v Krstić (Case No IT-9833-A), Judgment, 19 April 2004; Prosecutor v Blagojević (Case No IT-02-60-T), Judgment, 17 January 2005. In addition, in 2007, the International Court of Justice also found that Serbia had failed to prevent genocide at Srebrenica (but also that the state did not have the requisite specific intent to commit genocide), see Case Concerning the Application of the Convention on the Prevention and Punishment of the Crime of Genocide (Bosnia and Herzegovina v Serbia and Montenegro) (ICJ 140), Judgment, 26 February 2007. In late 2018, the Extraordinary Chambers in the Courts of Cambodia (ECCC) found Nuon Chea and Kheiu Samphan (Case $002 / 02$ ) guilty of genocide, but only with regard to the mass murder of the Vietnamese minority and Cham people, not killings and other acts which destroyed Cambodians more generally. On this case, and the ECCC's other cases, see Gidley (2019).

8) On "intent through action", see Barta (1987); Docker (2015). Compare with Greenawalt (1999).

9) See, for example, Elizabeth Brundige et al. (2004), Wing and King (2005), Asian Human Rights Commission (2013), and Elmslie and Webb-Gannon (2013). Many of these reports have been the subject of severe and often highly partial criticisms, not least of all by Indonesian sources. See Anderson (2015) and International Crisis Group (2006).

10) See Philpott (2018). In 2013, a group of academics, activists and survivors held a peoples' tribunal in Sydney, to make a legal case regarding the mass murder, torture, sexual violence, and other gross violations committed by Indonesian security forces personnel as part of crimes against humanity in the port town of Biak in July 1998, see Edwards (2017).

11) Aside from Anderson (2015), see also examples of how the Indonesian government denies abuses in West Papua at various international forums, such as the Universal Periodic Review. For example, on this last matter, that foreigners make up stories/misunderstand the situation "on the ground" in Papua, is a common refrain at these international forums, see Pohlman (2016).

12) On the elements of crime of genocide, see International Criminal Court (2011), pursuant to Article 6(a)-(e).

\section{REFERENCES}

Adams, S. (2019). 'If not now, when?': The Responsibility to Protect, the fate of the Rohingya and the future of human rights. Global Centre for the Responsibility to Protect, Occasional Paper Series, No. 8, January. Retrieved from http://www.globalr2p.org/media/ files/occasionalpaper_rohingyafinal.pdf.

Amnesty International (2018). Remaking Rakhines State. ASA 16/8018/2018, London: Amnesty International, 12 March 2018. Retrieved from https://www.amnesty.org/download/Documents/ ASA1680182018ENGLISH.PDF.

Anderson, B. (2015). Papua's insecurity: State failure in the Indonesian periphery. Policy Studies Washington, 73, 1-75.

Arcaro, P., \& Desaine, L. (2008). La junte Birmane contre "l'ennemi intérieur": La régime militaire, l'écrasement des minorités ethniques et le désarroi des réfugiés Rohingya. Paris: L'Harmattan.

Asian Human Rights Commission (2013). The neglected genocide: Human rights abuses against Papuans in the central highlands, 1977-78, Asian Human Rights Commission report, co-published with Human Rights and Peace for Papua, the International Coalition for Papua, Hong Kong, September 2013. Retreived from: http://www.tapol.org/sites/default/files/sites/default/ files/pdfs/NeglectedGenocideAHRC.pdf.

Aspinall, E., \& Berger, M. T. (2001). The break-up of Indonesia? Nationalisms after decolonization and the limits of the nation-state in post-Cold War Southeast Asia. Third World Quarterly, 22(6), 1003-1024.

Barta, T. (1987). Relations of genocide: Land and lives in the colonization of Australia. In I. Wallimann and M. N. Dobkowski (Eds.), Genocide and the modern age: Etiology and case studies of mass death (pp. 237-251). New York: Greenwood Press.

Becker, A. (2008). Penser et nommer les génocides: Raphaël Lemkin. Paper presented at Terror and the Making of Modern Europe: Transatlantic Perspectives on the History of Violence, Stanford University. Retrieved from http://stanford.edu/dept/france-stanford/ Conferences/Terror/BeckerFrench.pdf.

Beech, H., \& Nang, S. (2018). Myanmar rejects U.N. findings: 'No ethnic cleansing or genocide in our country'. The New York Times, 14 March 2018. Retrieved from https://www.nytimes.com/2018/03/14/world/asia/ un-myanmar-rohingya-genocide.html. 
Bloxham, D., \& Moses, A. D. (2010). Introduction: Changing themes in the study of genocide. In D. Bloxham \& A. D. Moses (Eds.), The Oxford handbook of genocide studies (pp. 1-15). Oxford: Oxford University Press.

Brass, P. R. (2003). The Partition of India and retributive genocide in the Punjab, 1946-47: Means, methods, and purposes 1. Journal of Genocide Research, 5(1), 71-101.

Brundige, E., King, W., Vahali, P., Vladeck, S., \& Yuan, X. (2004). Indonesian human rights abuses in West Papua: Application of the law of genocide to the history of Indonesian control, Allard K. Lowenstein International Human Rights Clinic, Yale Law School, 2004. Retrieved from: https://law.yale.edu/system/ files/documents/pdf/news/westpapuahrights.pdf.

Budiardjo, C., \& Liong, L. S. (1988). West Papua: The obliteration of a people, ( $3^{\text {rd }}$ ed.) London: TAPOL.

Callahan, M. P. (2013). Making enemies: War and statebuilding in Burma. Ithaca: Cornell University Press.

Caryl, C. (2017). In 2017, no one has fallen further than Aung San Suu Kyi. The Washington Post, 20 December. Retrieved from https:/www.washingtonpost.com/ news/democracy-post/wp/2017/12/20/in-2017-noone-has-fallen-further-than-aung-san-suu-kyi/?utm term $=.14 \mathrm{f} 7 \mathrm{f} 0425 \mathrm{c} 6 \mathrm{f}$.

Chauvel, R. (2005). Constructing Papuan nationalism: History, ethnicity, and adaptation. Policy Studies Washington, 14. Washington D.C.: East-West Center.

Cheesman, N. (2017). How in Myanmar 'national races' came to surpass citizenship and exclude Rohingya. Journal of Contemporary Asia, 47(3), 461-483.

Cheesman, N. (2015). Opposing the rule of law: How Myanmar's courts make law and order. Cambridge: Cambridge University Press.

Convention on the Prevention and Punishment of the Crime of Genocide, 9 December 1948, 78 U.N.T.S. 277 (entered into force 12 January 1951).

Cotton, J., \& Pohlman, A. (2011). The Responsibility to Protect in Viet Nam: Challenges, opportunities and cases for implementation. Working Paper on Viet Nam, The Asia Pacific Centre for the Responsibility to Protect, 28 May 2011. Retreived from https:// r2pasiapacific.org/filething/get/1347/VietNam Final_Report\%202011.pdf.

Darroch, G. P. (2009). Portraying Papua: Activist representations of Indonesian Papua 1969-2009. (Unpublished MPhil thesis). The Australian National University, Canberra, Australia.

Dikötter, F. (2010). Mao's great famine: The history of China's most devastating catastrophe, 1958-62. London: Bloomsbury.

Docker, J. (2015). A plethora of intentions: Genocide, settler colonialism and historical consciousness in Australia and Britain. The International Journal of Human
Rights, 19(1), 74-89.

Doctors Without Borders (2017). Myanmar: International humanitarian access to Rahkine state must be permitted. Doctors Without Borders Press Release, 18 September 2017. Retrieved from https://www. doctorswithoutborders.org/article/myanmarinternational-humanitarian-access-rakhine-statemust-be-permitted.

Edwards, N. (2017). The Biak massacre Citizens' Tribunal and the disputed Indonesian region of West Papua. In A. Byrnes \& G. Simms (Eds.), Peoples'Tribunals and international law (pp. 209-229). Cambridge: Cambridge University Press.

Elmslie, J., \& Webb-Gannon, C. (2013). Slow-motion genocide: Indonesian rule in West Papua. Griffith Journal of Law and Human Dignity, 1(2), 142-165.

Elmslie, J. (2010). West Papuan demographic transition and the 2010 Indonesian census: 'Slow motion genocide' or not? Centre for Peace and Conflict Studies, The University of Sydney, CPACS Working Paper No. 11/1, September 2010. Retrieved from: https://sydney. edu.au/arts/peace_conflict/docs/working_papers/ West_Papuan_Demographics_in_2010_Census.pdf. Gidley, R. (2019). Illiberal transitional justice and the Extraordinary Chambers in the Courts of Cambodia. Cham: Palgrave Macmillan.

Gravers, M. (2015). Disorder and order: The ethnonationalist struggle of the Karen in Burma/Myanmar - A discussion of the dynamics of an ethnicized civil war and its historical roots. Journal of Burma Studies, 19(1), 27-78.

Gravers, M. (2014). Politically engaged Buddhism - Spiritual politics or nationalist medium? In M. Gravers \& F. Ytzen (Eds.), Burma/Myanmar - Where now? (pp. 293-322). Copenhagen: NIAS Press.

Gravers, M., \& Ditlevsen, M. (2014). The religious dimension. In M. Gravers \& F. Ytzen (Eds.), Burma/ Myanmar-Where Now? (pp. 279-283) Copenhagen: NIAS Press.

Green, P., MacManus, T., \& de la Cour Venning, A. (2015). Countdown to annihilation: Genocide in Myanmar. London: International State Crime Initiative, Queen Mary University.

Greenawalt, A. K. A. (1999). Rethinking genocidal intent: The case for a knowledge-based interpretation. Columbia Law Review, 99, 2259-2294.

Grundy-Warr, C., \& Wong, E. (1997). Sanctuary under a plastic sheet: The unresolved problem of Rohingya refugees. IBRU Boundary and Security Bulletin, 5(3), 79-91.

Grünfeld, F., \& Vermeulen, W. (2009). Failures to prevent genocide in Rwanda (1994), Srebrenica (1995), and Darfur (since 2003). Genocide Studies and Prevention, 4(2), 221-237. 
Hernawan, B. (2017). Papua. The Contemporary Pacific, 29(2), 347-354.

Hernawan, B. (2018). Torture and peacebuilding in Indonesia: The case of Papua. New York: Routledge.

Hoey, B. A. (2003). Nationalism in Indonesia: Building imagined and intentional communities through transmigration. Ethnology, 42(2), 109-126.

Hoffstaedter, G. (2017). Dominant discourses of refugees, recognition, and othering in Malaysia. Situations: Cultural Studies in the Asian Context, 10(2), 27-44.

Human Rights Watch (2013). 'All you can do is pray': Crimes Against Humanity and ethnic cleansing of Rohingya muslims in Burma's Arakan state. Human Rights Watch, 22 April 2013. Retrieved from https:// www.hrw.org/report/2013/04/22/all-you-can-dopray/crimes-against-humanity-and-ethnic-cleansingrohingya-muslims.

Human Rights Watch (1996). Burma: The Rohingya muslims - ending a cycle of exodus. Human Rights Watch, Rep. No. 1079-2309, $9^{\text {th }}$ ed. Vol. 8. New York: Human Rights Watch. Retrieved from https://www. hrw.org/legacy/summaries/s.burma969.html.

Human Rights Watch (2015). Something to hide? Indonesia's restrictions on media freedom and rights monitoring in Papua. Human Rights Watch, 10 November 2015. Retrieved from https://www.hrw. org/report/2015/11/10/something-hide/indonesiasrestrictions-media-freedom-and-rights-monitoringpapua.

ICC (2019). Preliminary examination: Bangladesh/ Myanmar: Situation in the People's Republic of Bangladesh/Republic of the Union of Myanmar. International Criminal Court, ICC-01/12. Retrieved from www.icc-cpi.int/rohingya-myanmar.

Irvin-Erickson, D., La Pointe, T., \& Hinton, A. L. (2013). Introduction: Hidden genocides: Power, knowledge, memory. In A. L. Hinton, T. La Pointe \& D. Irvin-Erickson (Eds.), Hidden genocides: Power, Knowledge, memory (pp. 1-20). New Brunswick: Rutgers University Press.

International Criminal Court (2011). Elements of Crime. The Hague: ICC, ICC-PIDS-LT-03-002/11_Eng; UN Doc. PCNICC/2000/1/Add.2 (adopted 30 June 2000).

International Criminal Court (2018). Statement of ICC Prosecutor, Mrs Fatou Bensouda, on opening a preliminary examination concerning the alleged deportation of the Rohingya people from Myanmar to Bangladesh. Retrieved from https://www.icc-cpi.int/ Pages/item.aspx?name=180918-otp-stat-Rohingya.

International Crisis Group (2002). Indonesia: Resources and conflict in Papua. ICG Asia Report 39, 13 September 2002. Retrieved from https://d2071andvip0wj. cloudfront.net/39-indonesia-resources-and-conflictin-papua.pdf.
International Crisis Group (2006). Papua: Answers to frequently asked questions. ICG Asia Briefing 53, 5 September 2006. Retrieved from: http://www. refworld.org/docid/4517d6884.html.

Jahan, R. (2009). Genocide in Bangladesh. In S. Totten \& W. S. Parsons (Eds.), Century of genocide: Critical essays and eyewitness accounts ( $3^{\text {rd }}$ ed.), (pp. 245266). New York: Routledge.

Leider, J. P. (2016). Competing identities and the hybridized history of the Rohingyas. In R. Egreteau \& F. Robinne (Eds.), Metamorphosis: Studies in social and political change in Myanmar (pp. 151-178). Singapore: NUS Press.

Lemkin, R. (1944). Axis rule in occupied Europe: Laws of occupation. Washington D.C.: Carnegie Endowment for International Peace.

Lindblom, A., Marsh, E., Motala, T., \& Munyan, K. (2015). Persecution of the Rohingya Muslims: Is genocide occurring in Myanmar's Rakhine state? A legal analysis. New Haven: Allard K. Lowenstein International Human Rights Clinic, Yale Law School.

Luban, D. (2006). Calling genocide by its rightful name: Lemkin's word, Darfur, and the UN report. Chicago Journal of International Law, 7(1), 303-320.

Macleod, J. (2015). Merdeka and the morning star: Civil resistance in West Papua. St Lucia: University of Queensland Press.

Mayersen, D. (2013). 'Never again' or again and again: The Genocide Convention, the responsibility to protect and mass atrocity prevention. In D. Mayersen \& A. Pohlman (Eds.), Genocide and mass atrocities in Asia: Legacies and prevention (pp. 177-196). New York: Routledge.

Melvin, J., \& Pohlman, A. (2018). A case for genocide: Indonesia, 1965-1966. In K. McGregor, J. Melvin \& A. Pohlman (Eds.), The Indonesian genocide of 1965: Causes, dynamics and legacies (pp. 27-46). New York: Palgrave Macmillan.

Moreton-Robinson, A. (2003). I still call Australia home: Indigenous belong and place in a white postcolonizing society. In S. Ahmed (Ed.), Uprootings/regroundings: Questions of home and migration (pp. 23-40). New York: Berg.

Moses, A. D. (2002). Conceptual blockages and definitional dilemmas in the 'racial century': Genocides of indigenous peoples and the Holocaust. Patterns of Prejudice, 36(4), 7-36.

Moses, A. D. (2018). Raphael Lemkin, culture, and the concept of genocide. In D. Bloxham \& A. D. Moses (Eds.), The Oxford handbook of genocide studies (pp. 19-41). New York: Oxford University Press.

Muller, A. (2017). Troubling history, troubling law: The question of indigenous genocide in Canada. In S. W. Murray (Ed.), Understanding atrocities: 
Remembering, representing, and teaching genocide (pp. 83-106). Calgary: University of Calgary Press. Murdoch, L. (2017). 'Shameful tactic': Myanmar bars top UN investigator from entering the country. The Sydney Morning Herald, 20 December 2017. Retrieved from https://www.smh.com.au/world/ shameful-tactic-myanmar-bars-top-un-investigatorfrom-entering-the-country-20171220-h089ew.html.

Murray, S. W. (Ed.). (2017). Understanding atrocities: Remembering, representing, and teaching genocide. Calgary: University of Calgary Press.

Note to correspondents: Statement by Adama Dieng, United Nations Special Advisor on the Prevention of Genocide, on his visit to Bangladesh to assess the situation of Rohingya refugees from Myanmar. United Nations Secretary-General, Office on Genocide Prevention and the Responsibility to Protect, 12 March 2018. Retrieved from https://www.un.org/ sg/en/content/sg/note-correspondents/2018-03-12/ note-correspondents-statement-adama-dieng-unitednations.

OHCHR (2017). Mission report of OHCHR rapid response mission to Cox's Bazar, Bangladesh, 1324 September 2017. United Nations Human Rights Office of the High Commissioner, 11 October 2017. Retrieved from http:/www.ohchr.org/Documents/ Countries/MM/CXBMissionSummaryFindingsOct ober2017.pdf.

Penders, C. L. M. (2002). The West New Guinea debacle: Dutch decolonization and Indonesia, 1945-1962. Honolulu: University of Hawai'i Press.

Philpott, S. (2018). This stillness, this lack of incident: Making conflict visible in West Papua. Critical Asian Studies, 50(2), 259-277.

Pohlman, A. (2016). Indonesia and the UN Genocide Convention: The empty promises of human rights ritualism. In D. Mayersen (Ed.), The United Nations and genocide (pp. 128-132). London: Palgrave Macmillan.

Powell, C. (2004). Civilization and genocide. (Doctoral dissertation, Carleton University, Ottawa, Canada).

Powell, C. (2007). What do genocides kill? A relational concept of genocide. Journal of Genocide Research, $9(4), 527-547$.

Report of the independent international fact-finding mission on Myanmar. UN Doc. A/HRC/39/64 (Advance Unedited Version) (12 September 2018). Retrieved from https:/www.ohchr.org/Documents/HRBodies/ HRCouncil/FFM-Myanmar/A_HRC 39 64.pdf.

Robinson, I. G., \& Rahman, I. S. (2012). The unknown fate of the stateless Rohingya. Oxford Monitor of Forced Migration, 2(2), 16-20.

Rosenberg, S. P. (2012). Genocide is a process, not an event. Genocide Studies and Prevention, 7(1), 16-23.
Rutherford, D. (1999). Waiting for the end in Biak: Violence, order, and a flag raising. Indonesia, 67, 39-59.

Saltford, J. (2002). The United Nations and the Indonesian takeover of West Papua, 1962-1969: The anatomy of betrayal. London: RoutledgeCurzon.

Sardiña Galache, C. (2014). Rohingya and national identities in Burma. New Mandala, 22 September 2014. Retreived from http:/www.newmandala.org/therohingya-and-national-identities-in-burma/.

Saul, B. (2001). Was the conflict in East Timor 'genocide' and why does it matter? Melbourne Journal of International Law, 2(2), 477-522.

Schaller, D. J. (2011). Genocide in colonial South-West Africa: The German war against the Herero and Nama, 1904-1907. In S. Totten \& R. K. Hitchcock (Eds.), Genocide of indigenous peoples: A critical biographic review (pp. 37-60). New Brunswick: Transaction.

Schwirtz, M. (2018). U.S. Holocaust Museum revokes award to Aung San Suu Kyi. The New York Times, 7 March. Retrieved from https://www.nytimes. com/2018/03/07/world/asia/aung-san-suu-kyiholocaust-rohingya.html.

Shaw, M. (2015). What is Genocide? (2 ${ }^{\text {nd }}$ ed.). Cambridge, Polity Press.

Shelton, T. (2019). Myanmar's military 'unleashes campaign of violence' in Rakhine state, Amnesty International warns. ABC News, 29 May 2019. Retrieved from https://www.abc.net.au/news/2019-05-29/newreport-details-war-crimes-and-abuses-in-myanmarsrakhine/.

Short, D. (2016). Redefining genocide: Settler colonialism, social death and ecocide. London: Zed Books.

Simpson, B. (2003). "Power, Politics, and Primitivism: West Papua's Struggle for Self-Determination," Critical Asian Studies, 35(3), 469-475.

Southwick, K. (2015). Preventing mass atrocities against the stateless Rohingya in Myanmar: A call for solutions. Journal of International Affairs, 68(2), 137-156.

Stone, D. (2008). Introduction. In D. Stone (Ed.), The historiography of genocide (pp. 1-6). New York: Palgrave Macmillan.

Wing, J., \& King, P. (2005). Genocide in West Papua? The role of the Indonesian state apparatus and a current needs assessment of the Papuan people. Sydney: CPACS, University of Sydney.

Wolfe, P. (2006). Settler colonialism and the elimination of the native. Journal of Genocide Research, 8(4), 387-409.

Yang Su (2011). Collective killings in rural China during the Cultural Revolution. New York: Cambridge University Press.

Yegar, M. (1982). The Muslims of Burma. In R. Israeli (Ed.), The crescent in the East: Islam in Asia Minor (pp. 
102-139). London: Curzon Press.

Zarni, M., \& Cowley, A. (2014). The slow-burning genocide of Myanmar's Rohingya. Pacific Rim Law and Policy Journal, 23(3), 683-754.
Zavis, A. (2014). Myanmar orders Doctors Without Borders to cease operations. LA Times, 28 February 2014. Retreived from http://www.latimes.com/world/ worldnow/la-fg-wn-myanmar-orders-doctorswithout-borders-to-cease-operations-20140228-story. html. 